\title{
Strategi Redaksi Media Online Okezone.com dalam Menarik Minat Generasi Milenial
}

\author{
Natasha Oktalia, Farid Rusdi \\ natashaoktalia3010@gmail.com,farid@fikom.untar.ac.id \\ Fakultas Ilmu Komunikasi Universitas Tarumanagara
}

\begin{abstract}
Online media currently has a target audience among millennials. This is because online media uses a number of platforms or portals like social media which are widely used by millennials, such as Instagram, Youtube, Facebook, and others. Online media upload a number of content and articles every day. This research is to determine the online.com media editorial strategy in attracting the interest of the millennial generation. The research method used in this research is a qualitative research method with a case study approach and interviews. The results of this study indicate that the strategy of Okezone.com online media to attract the millennial generation's greatest interest is the use of social media and using a number of features that have been provided from social media. The use of social media is very interesting and gets a lot of attention from the millennial generation and is considered effective. The Okezone.com method is considered effective and appropriate in the use of social media as a forum or a way to attract this interest. In addition, one of the very interesting advantages of online media is the speed with which information circulates on the internet, so that readers or audiences can quickly find out what phenomena or information is currently viral or taking place and only use the help of an internet connection.
\end{abstract}

Keywords: editorial strategy, instagram, social media

\begin{abstract}
Abstrak
Media online saat ini memiliki target pembaca di kalangan milenial. Hal ini karena media online menggunakan sejumlah wadah atau portal layaknya media sosial yang banyak digunakan oleh milenial, seperti Instagram, Youtube, Facebook, dan lain-lain. Media online menggunggah sejumlah konten dan artikel setiap harinya. Penelitian ini guna mengetahui strategi redaksi media online.com dalam menarik minat generasi milenial. Metode penelitian yang digunakan dalam penelitian ini merupakan penelitian dengan metode kualitatif dengan pendekatan studi kasus dan wawancara. Hasil penelitian ini menunjukkan bahwa strategi dari media online Okezone.com untuk menarik minat generasi milenial salah satu yang terbesarnya adalah dengan penggunaan media sosial dan menggunakan sejumlah fitur yang sudah disediakan dari media sosial tersebut. Pengguanaan media sosial sangat menarik dan mendapatkan banyak perhatian dari generasi milenial dan dianggap efektif. Cara Okezone.com dinilai efektif dan tepat dalam penggunaan media sosial sebagai wadah atau cara menarik minat tersebut. Selain itu, salah satu keunggulan yang sangat menarik pada media online adalah cepatnya informasi yang beredar di jejaring internet, sehingga para pembaca atau audience dengan cepat dapat mengetahui fenomena atau apa kejadian dan informasi yang sedang viral atau berlangsung dan hanya menggunakan bantuan dari koneksi internet.
\end{abstract}

Kata Kunci: instagram, media sosial, strategi redaksi 


\section{Pendahuluan}

Generasi milenial adalah mereka yang lahir pada era tahun 1980 hingga 2000. Generasi ini sering dikatakan sebagai Gen-Y, Net Generation, Generation WE, Boomerang Generation, Peter Pan Generation, dsb (Yuswohady, 2016). Generasi milenial sering kali dikatakan sebagai generasi Milenium, sebab merekalah generasi yang hidup dipergantian millennium. Lancaster \& Stillman (2002), Generasi Y atau dikenal sebagai generasi milenial atau millennium. Bisa dikatakan generasi milenial adalah mereka yang lahir ditengah pesatnya kemajuan teknologi.

Adapula beberapa karakteristik menonjol dari generasi milenial di antaranya yakni milenial yang lebih percaya pada User Generated Content (UCG) atau konten bahkan informasi yang dibuat oleh perorangan berdasarkan hasil studi yang dilakukan oleh Boston Consulting Group (Bona et al., 2020). Milenial lebih memilih dengan adanya handphone jika dibandingkan dengan televisi, sudah bukan menjadi rahasia bahwa milenial dipastikan memiliki media sosial, lebih mengetahui perkembangan tekonologi, dan tentunya mereka akan lebih memanfaatkan adanya teknologi dan informasi.

Inovasi yang ada dalam bidang teknologi informasi atau komunikasi ini sangat memberi perubahan yang besar terhadap kehidupan masyarakat. Dengan adanya perkembangan yang pesat dalam dunia digital saat ini tentunya membantu masyarakat semakin mudah dalam mendapatkan informasi dan pengetahuan. Selain itu, penggunaan penyebaran berita melalui media online sudah banyak dilakukan oleh sejumlah portal berita.

Apalagi saat ini media online menjadi salah satu tempat untuk menyalurkan sejumlah informasi baik dalam bentuk pesan, video bahkan foto. Proses penyebaran berita melalui media online saat ini terbilang mudah dan tidak membutuhkan banyak waktu. Cukup dengan bantuan koneksi internet dan sarana pendukung, dengan cepat informasi akan segar menyebar. Ashadi Siregar mengatakan bahwa media online dapat diartikan sebagai sebuah sebutan umum untuk sebuah bentuk media yang berbasis telekomunikasi dan multimedia (komputer dan internet.). Sementara itu, menurut Romli (2012), media online merupakan media massa yang tersaji secara online atau tersaji dalam situs web (website) internet.

Selain itu, di zaman saat ini banyak pula generasi milenial yang terjun langsung dalam dunia media atau sebagai jurnalis. Jika dilihat secara seksama, memang terdapat perbedaan gaya penulisan pada jurnalis media cetak dengan media online. Tidak heran jika saat ini sejumlah lapangan usaha didominasi oleh kalangan milenial. Penulisan pada media online biasanya lebih ringkas dan singkat namun tidak menghilangkan nilai dari suatu berita. Sementara penulisan pada media cetak umumnya lebih kompleks dan baku. Dilihat dari apa yang terjadi saat ini, milenial tentunya akan memilih untuk lebih membaca media online ketimbang media cetak seperti koran, majalah atau tabloid. Banyak pula media online saat ini yang menyajikan portal berita layaknya kanal lifestyle, kuliner, musik, otomotif, olahraga bahkan ekonomi sekalipun dengan tetap dengan sasaran utama yakni generasi Milenial.

Seperti yang terjadi saat ini, penulis melihat bahwa media online selalu mempunyai cara masing-masing untuk menarik minat milenial. Entah dari pembuatan nama yang unik dalam suatu kanal atau cara lainnya. Salah satu media online yang dilihat oleh Penulis menarik yakni Okezone.com, yang merupakan salah satu portal berita milik PT Media Nusantara Citra Tbk (MNC). 
Dalam menarik minat para milenial bukan perkara mudah bagi sebuah media. Hal ini membutuhkan sejumlah strategi agar media tersebut diminati dan menarik minat para milenial. Okezone.com sendiri memiliki keunggulan seperti hadirnya sejumlah konten yang dibuat rinci dan dimaksudkan agar menarik minat pembaca seperti menggunakan media sosial Instagram untuk mengajak para audience atau pembaca dapat ikut berperan dalama tayangan Instagram Live, lalu dengan ada hadirnya konten berita umum, politik, peristiwa, internasional, ekonomi, lifestyle, selebriti, sports, bola, auto, teknologi, travel, food, Haji dan Muslim, IDX.

\section{Metode Penelitian}

Penelitian ini menggunakan metode penelitian kualitatif. Menurut Strauss dan Corbin (2003), penelitian kualitatif merupakan suatu penelitian yang hasil temuannya tidak diperoleh melalui prosedur statistik atau bentuk hitungan. Dengan begitu, sangat jelas seperti apa yang dikutip dari Anslem bahwa penelitian dengan metode ini merupakan jenis penelitian tanpa adanya pengumpulan data atau Teknik perhitungan.

Hal serupa juga dikatakan oleh Sugiyono (2010), penelitian kualitatif merupakan metode penelitian yang digunakan untuk penelitian, meneliti pada kondisi obyek yang bersifat alamiah, yang dimana peneliti sebagai instrument kunci. Lalu, untuk pengumpulan data sendiri dilakukan secara triangulasi (gabungan). Nantinya, pada hasil analisis nanti akan menghasilkan data akhir yang bersifat induktif dan hasil dari penelitian dengan metode kualitatif akan lebih menekankan makna dari pada generalisasi. Adanya penelitian ini guna mengetahui strategi redaksi media online.com dalam menarik minat generasi milenial yang berisikan dengan data, gambaran, serta analisis tentang Okezone.com. Oleh karena itu, penulis memilih metode kualitatif sebagai pendekatan penelitian.

\section{Hasil dan Temuan}

Okezone.com sendiri merupakan sebuah portal berita media massa yang dipasarkan atau mengembangkan sayap dalam dunia internet. Dalam artian, Okezone.com sangat membutuhkan bantuan internet dalam perjalanan industrinya. Hal tersebut juga dibuktikan dengan penggunaan beberapa platform pada media sosial seperti penggunaan Instagram, Facebook, YouTube, dan lain-lain.

Penggunaan media sosial tersebut terbukti sangat efektif dan berpengaruh dalam kegiatan sehari-hari. Apalagi, target terbesar Okezone.com lebih menekankan kepada usia atau generasi milenial. Tentunya, generasi milenial tersebut tidak bisa dipisahkan dari penggunaan media sosial. Selain itu, penggunaan media sosial tersebut digunakan untuk menggunggah sejumlah konten harian bahkan acara-acara yang digelar sekaligus. Seperti salah satunya penggunaan Instagram TV yang dilakukan di account Instagram milik Okezone.com, dalam laman tersebut, Okezone.com sering mengadakan tayangan Live dengan sejumlah narasumber milenial atau narasumber lainnya.

Okezone.com sering mengadakan tayangan Live dengan sejumlah narasumber milenial atau narasumber lainnya. Tentunya, adanya tayangan dengan sejumlah narasumber tersebut sangat menarik minat para audience. Apalagi dengan pemilihan sejumlah narasumber yang sedang banyak diminati kalangan milenial, menjadi salah satu daya tarik bagi audience untuk menonton tayangan tersebut. 
Tidak hanya itu, sebelum adanya Pandemic Okezone.com secara rutin menggelar acara tahunan rutin yang diadakan di beberapa kampus. Yakni Okezone.com Goes to Campus. Acara tersebut tentunya menarik banyak minat generasi milenial. Selain itu, ditengah pesatnya kemajuan teknologi dalam bidang game online. Okezone.com juga mendukung adanya acara semacam perlombaan $e$ sport. Sejumlah strategi atau cara yang diambil Okezone.com dinilai sudah tepat dan efektif dalam hal menarik audience dari kalangan milenial. Sebab, memang saat ini jika dilihat dari data insight yang dimiliki rata-rata audience berada di angka atau usia muda yakni 19-35 tahun.

\section{Kesimpulan}

Berdasarkan penelitian dan pembahasan mengenai strategi redaksi yang dilakukan dan dilaksanakan oleh Okezone.com dalam menarik minat generasi milenial dengan cara menggunakan aplikasi atau platform seperti Instagram, Youtube, Facebook, dan lain-lainnya.

Dalam penggunaan aplikasi Instagram tersebut, untuk menarik audience menggunakan cara seperti mengadakan tayangan live dengan sejumlah narasumber atau pembicara yang cocok dan berpengalaman. Selain itu, melakukan postingan melaui feeds dan instastory. Kesimpulan lainnya yakni, Okezone.com dengan beberapa media partner lainnya mengadakan beberapa acara-acara seperti perlombaan e-sport, game competition dengan menayangkannya secara live dengan maksud dan tujuan bahwa Okezone.com mendukung generasi milenial.

Lainnya yakni dengan menyelenggarakan salah satu kegiatan rutin tahunan yaitu Okezone Goes to Campus. Namun, sayangnya di tahun ini acara rutin tersebut tidak dapat dijalankan sebab adanya pandemic Covid-19. Dengan melaksanakan kegiatan Goes to Campus tersebut, Okezone.com berhasil menarik dan mendapatkan audience di kalangan milenial. Sebab, konten atau hasil yang dihasilkan dari acara tersebut benar-benar mengarah pada milenial.

\section{Ucapan Terima Kasih}

Penulis mengucapkan banyak terima kasih kepada Fakultas Ilmu Komunikasi Universitas Tarumanagara, Keluarga, Kerabat serta teman Penulis yang selalu memberikan semangat dan dukungan yang berarti, oleh karena hal tersebut pula Penulis dapat menyelesaikan proses penelitian ini.

\section{Daftar Pustaka}

Bona, Carmen., Koslow, Lara., Frantz, Renee., NAdres, Brian., \& Ratajczak, David. (2020). How Marketers Can Win with Gen $Z$ and Millennials Post-COVID19. Report. Diakses di https://www.bcg.com/publications/2020/howmarketers-can-win-with-gen-z-millennials-post-covid.

Lancaster, L. C., \& Stillman, D. (2002). When Generations Collide: Who They Are. Why They Clash. How to Solve the Generational Puzzle at Work. New York: Harper Collins.

Romli, A. S. M. (2012). Jurnalistik online: Panduan mengelola media online. Bandung: Nuansa Cendekia.

Strauss, A., \& Corbin, J. (2003). Penelitian Kualitatif. Yogyakarta: Pustaka Pelajar. 
Natasha Oktalia, Farid Rusdi: Strategi Redaksi Media Online Okezone.com dalam Menarik Minat Generasi Milenial

Sugiyono. (2010). Metode Penelitian Pendidikan Pendekatan Kuantitatif, Kualitatif, dan $R \& D$. Bandung: Alfabeta.

Yuswohady. (2016). Millennial Trends 2016. Report. Diakses dari http:/www.yuswohady.com/2016/01/1 7/millennial-trends-2016/. 